\title{
PENINGKATAN KUALITAS PENGELOLAAN DAN PRODUKTIVITAS UKM PADA KELOMPOK PEMBATIK DESA PLANA DAN SOKAWERA KECAMATAN SOMAGEDE KABUPATEN BANYUMAS
}

\author{
Aldila Krisnaresanti $^{1 *}$, Nurul Hidayat ${ }^{2}$, Viviana Mayasari $^{1}$ dan Sri Lestari $^{1}$ \\ ${ }^{1}$ Fakultas Ekonomi dan Bisnis, Universitas Jenderal Soedirman Purwokerto \\ ${ }^{2}$ Fakultas Sains dan Teknik, Universitas Jenderal Soedirman Purwokerto \\ *Corresponding author : aldila.krisna2104@gmail.com
}

Received 23 May 2019; Accepted 2019; Available online 2019

\begin{abstract}
Abstrak
Masalah utama dalam Grup Batik Sekar Geang dan Capit Urang adalah tidak adanya pembagian tugas dalam kelompok. Semua anggota kelompok mengerjakan kegiatan produksi, tidak ada pembagian kerja dalam kelompok, tidak ada anggota yang tugasnya memasarkan produk mereka, mitra tidak melakukan kegiatan administrasi kelompok secara tertib, belum ada upaya dari kelompok untuk mempromosikan produk mereka kepada masyarakat, belum mengenal pemasaran on-line untuk produk batik, kurangnya modal dan peralatan produksi untuk menjalankan bisnisnya, tidak memiliki keterampilan dan peralatan untuk menghasilkan pencetakan batik yang sangat prospektif untuk melayani seragam anakanak sekolah, guru dan staf di Kecamatan Somagede, Desain motif batik kedua mitra masih terbatas dan beragam, desain pengemasan dan label masih sangat sederhana, kemampuan manajemen usaha kecil masih terbatas dan pembukuan belum sesuai standar. Kegiatan sasaran adalah peningkatan kemampuan mitra dalam manajemen dan administrasi kelompok, hasil administrasi kegiatan kelompok, sistem pembagian kerja, peningkatan penjualan, layanan pemasaran on-line, desain batik baru, batik printing, pengemasan dan pelabelan produk dengan desain menarik, kelompok keuangan laporan, dan jurnal ilmiah. Untuk mencapai tujuan, dilakukan kegiatan seperti penyuluhan, praktik, dan pendampingan. Metode evaluasi yaitu dengan membandingkan tingkat pengetahuan dan kemampuan mitra, serta kinerja produksi dan pemasaran sebelum dan sesudah kegiatan.
\end{abstract}

Kata Kunci : Kelompok Batik, Batik Printing, Manajemen Usaha Kecil, Manajemen dan Administrasi Kelompok

\section{Abstract}

The main problem in Group Batik Sekar Geang and Capit Urang is the absence of partners the division of tasks within the group. All members of the group working on production activities, there is no division of labor within the group, no member whose job is to market their products, partners do not perform registration activities group administration in an orderly manner, there has been no attempt of a group to promote their products to the public, are not familiar with marketing on -line for batik products, lack of capital and production equipment to run its business, does not have the skills and equipment to produce 
batik printing highly prospective for serving uniform school children, teachers and staff in the District Somagede, Design batik motif both partners is still limited and yet varied, packaging and label design is still very modest, small business management capabilities are limited and not yet standardized bookkeeping. Target activities are increased capability partner in the management and administration of the group, the results of administrating the group's activities, a system of division of labor, an increase in sales, marketing services online, the design of new batik, batik printing, packaging and labeling of products with attractive design, report financial groups, and scientific journals. To achieve the objectives and outcomes, activities such as counseling, practice, support. The evaluation method by comparing the level of knowledge and ability as well as the performance of the production and marketing partners before and after the activities.

Keywords: Group Batik, Batik Printing, Small Business Management, Management and Administration Group

\section{PENDAHULUAN}

Salah satu cara untuk mendapatkan ide bisnis yang disukai adalah dengan melakukan pengamatan atas segala sesuatu yang terjadi di sekitar kita (Pramudiana, 2017). Kelompok Usaha Bersama Sekar Geang dan Kelompok Batik Capit Urang adalah kelompok pembatik yang terletak di Kecamatan Somagede Kabupaten Banyumas yang mendirikan usahanya dengan melihat peluang yang ada di sekitarnya dan memanfaatkan potensi yang dimilikinya. Produk batik dari KUBE Sekar Geang dan Capit Urang merupakan salah satu produk unggulan Kecamatan Somagede. Kelompok Usaha Bersama Sekar Geang beralamat di Desa Plana Rt 06/05 Kecamatan Somagede Kabupaten Banyumas diketuai oleh ibu Jaenaturohmah. Sedangkan Kelompok Pembatik Capit Urang berlokasi di RT 02/Rw I Desa Sokawera Kecamatan Somagede dan berdiri pada tanggal 10 Desember 2013. Kelompok ini terbentuk dari anggota kelompok Simpan Pinjam Perempuan yang dibentuk oleh UPK PNPM Mandiri Perdesaan pada saat lembaga tersebut masih ada.

Seperti halnya KUBE Sekar Geang, kelompok pembatik Capit Urang juga melakukan kegiatan kelompok secara sederhana dengan melakukan pertemuan rutin dan melakukan usaha simpan pinjam yang dilakukan setiap bulan. Struktur organisasi kelompok ini juga hanya terdiri dari ketua, bendahara, sekertaris dan anggota. Pembagian pekerjaan di dalam kelompok ini juga belum ada, hanya bendahara yang bertugas melakukan pembukuan dan sekertaris yang melakukan pencatatan. Kegiatan produksi dan pemasaran dilakukan secara bersama-sama. Hasil produksi Kelompok Pembatik Capit Urang sebagian besar berupa batik printing kombinasi. Selama satu bulan dari kelima belas orang anggotanya dapat memproduksi rata-rata 40-45 buah kain batik tulis dan batik printing kombinasi, sebagian besar juga berupa batik printing kombinasi.

Saat ini walaupun hasil produksi batik tulis dan batik printing kombinasi kedua kelompok sudah bagus namun keterampilan dalam memasarkan produk mereka masih sangat terbatas. Diantara anggota kelompok tidak ada pembagian tugas pekerjaan, semua melakukan kegiatan produksi tidak ada yang bertugas melakukan kegiatan pemasaran. Dengan hanya menghasilkan batik tulis dan batik printing kombinasi, kedua kelompok ini belum dapat memenuhi pesanan dalam partai besar untuk produk-produk yang murah, terutama pesanan yang berupa kain-kain batik untuk seragam sekolah. Selama ini kebutuhan batik untuk murid sekolah, guru dan karyawan di Kecamatan Somagede masih banyak dipenuhi dari luar Kecamatan Somagede. Disamping itu bahan batik printing kombinasi juga harus dibeli dari Persatuan Batik Indonesia (PERBAIN) yang berlokasi di Sokaraja dengan jarak $10 \mathrm{~km}$ dari Kecamatan Somagede. Oleh karena itu kedua kelompok sangat mengharapkan diberi 
keterampilan batik printing agar diversifikasi produk yang dihasilkannya lebih banyak dan dapat melayani konsumen dalam jumlah yang lebih banyak lagi.

Anggota kelompok ini sangat menginginkan dapat memproduksi batik printing agar bisa memproduksi batik dalam partai besar dengan harga yang terjangkau dan dapat melayani pesanan seragam anak-anak sekolah dan para pegawai di lingkungan kecamatan Somagede. Disamping itu jika mereka bisa mempunyai alat screen printing dan bisa memproduksi batik printing sendiri maka mereka tidak perlu membeli bahan batik printing kombinasi ke PERBAIN lagi.

Masalah lain yang sangat perlu diperhatikan adalah tentang manajemen usaha yang dijalankan pada kedua kelompok. Dari hasil wawancara dan observasi diketahui bahwa selama ini manajemen usaha yang dijalankan masih sangat sederhana, baik dalam hal pengelolaan keuangan, administrasi, SDM, Pemasaran maupun produksinya. Disamping itu label dan kemasan yang digunakan masih sangat sederahana, promosi hanya dilakukan dari mulut ke mulut.

Berdasarkan penggalian informasi dan observasi, tim pengabdian menyimpulkan bahwa KUBE Sekar Geang dan Kelompok Pembatik Capit Urang mempunyai potensi yang sangat besar untuk dikembangkan. Mereka memiliki tenaga terampil yang melimpah dan murah, serta komitmen kelompok yang tinggi untuk maju bersama-sama. Disamping itu jika kedua kelompok ini benar-benar menjadi produsen batik yang besar maka akan dapat membuka kesempatan kerja bagi 4.641 orang yang menganggur. Oleh karena itu sangat diperlukan pembinaan terhadap kedua kelompok pembatik ini. Kedua kelompok sangat mengharapkan diadakannya kegiatan pengabdian di kelompok mereka.

Berdasarkan observasi yang dilakukan oleh tim pengabdian maka permasalahanpermasalahan yang ada pada mitra kegiatan dapat diurutkan sesuai prioritasnya sebagai berikut:

1. Permasalahan yang paling urgen dan harus segera diatasi adalah tidak adanya pembagian tugas di dalam kelompok.

2. Kelompok belum melakukan kegiatan pencatatan administrasi kelompok dengan tertib. Pengadministrasian kelompok dilakukan dengan sangat sederhana.

3. Belum ada usaha dari kelompok untuk mempromosikan produknya ke masyarakat, padahal produk yang dihasilkan sudah sangat layak dijual dan memungkinkan penjualan dalam volume yang besar jika diketahui masyarakat secara luas. Saat ini pemasaran produk kedua mitra masih bersifat konvensional, penjualan berdasarkan pesanan dan promosi hanya dari mulut ke mulut, serta belum mengenal penjualan online.

4. Permasalahan kekurangan modal dan peralatan produksi untuk menjalankan usahanya. Kedua kelompok menginginkan dapat membuat batik printing agar dapat melayani seragam dalam jumlah yang besar, terutama seragam anak-anak sekolah di Kecamatan Somagede. Untuk dapat melayani pesanan seragam dalam partai besar dengan harga murah dapat dilayani dengan batik printing, namun kedua mitra belum memiliki keterampilan dan alat untuk membuat batik printing.

5. Desain motif batik yang dimiliki dan diproduksi oleh kedua mitra pembatik masih terbatas dan belum bervariatif.

6. Desain kemasan dan label produk kedua mitra yang ada masih sangat sederhana.

7. Kedua mitra mempunyai kemampuan manajemen usaha kecil yang terbatas dan belum melaksanakan pembukuan yang tertata dengan baik dan teratur.

Dengan memperhatikan permasalahan permasalahan yang dihadapi oleh kedua mitra program tersebut maka tujuan kegiatan ini adalah : Meningkatkan pengetahuan dan ketrampilan berusaha pada kedua kelompok dalam mengelola kelompok, meningkatkan 
kemampuan pengadministrasian kelompok; meningkatkan kemampuan memasakan hasil produksinya termasuk menggunakan pemasaran on-line; memberikan pelatihan dalam membuat batik printing; memberikan bantuan alat screen printing; mengembangkan kemampuan dalam merancang desain produk batik yang bervariatif dan desain kemasan serta label yang menarik; serta memberikan penyuluhan tentang manajemen usaha kecil yang baik serta praktek penyusunan laporan keuangan yang baik.

\section{METODE ANALISIS}

Tim pengabdian IbM menyediakan bantuan dan pendampingan secara manajerial guna meningkatkan "status usaha" kedua mitra agar fleaksible dan bankable dalam jangka panjang. Kegiatan pengabdian yang akan dilakukan bagi kedua mitra dan telah disepakati oleh Tim Pengabdian dengan kedua mitra berupa kegiatan penyuluhan, praktek dan pendampingan.

Adapun uraian prosedur kerja untuk mendukung realisasi program dengan menggunakan metode yang telah disepakati bersama mitra adalah sebagai berikut :

\section{Meningkatkan kemampuan mitra dalam mengelola kelompok dan menyusun administrasi kelompok.}

Metode yang digunakan untuk memecahkan masalah ini adalah dengan penyuluhan, praktek serta pendampingan kepada mitra. Pada kegiatan ini tim pengabdian akan bertindak sebagai pelatih sedangkan mitra akan berperan sebagai objek pelatihan. Beberapa kegiatan akan dilaksanakan berkaitan dengan peningkatan kemampuan mitra dalam hal pengelolaan kelompok dan penyusunan administrasi kelompok yaitu :

1) Penyuluhan dan praktek tentang manajemen kelompok. Kegiatan ini bertujuan untuk meningkatkan pengetahuan pengurus dan anggota kelompok tentang cara-cara melakukan kegiatan kelompok dan pentingnya pembagian tugas di dalam kelompok. Kegiatan ini dilanjutkan dengan praktek pembagian tugas di dalam kelompok. Pada kegiatan ini, tim pengabdian berperan sebagai pelatih sedangkan mitra berpartisipasi sebagai objek pelatihan.

2) Penyuluhan dan praktek administrasi kelompok. Kegiatan ini bertujuan untuk memberikan pemahaman tentang arti pentingnya mengadministrasikan semua kegiatan kelompok dengan benar. Penyuluhan yang diberikan meliputi pengertian kelompok, Anggaran Dasar dan Anggaran Rumah Tangga Kelompok serta kegunaan adminstrasi kelompok. Keuangan. Kegiatan selanjutnya praktek pembuatan administrasi kelompok. Administrasi Organisai kelompok terdiri dari : 1) Buku agenda surat; 2) Buku anjuran; 3) Buku daftar anggota; 4) Buku daftar hadir kegiatan; 5) Buku ekspedisi; 6) Buku inventaris; 7) Buku Kas; 8) Buku Kegiatan; 9) Buku saran anggota; 10) Buku susunan pengurus; dan 11) Buku tamu. Pada kegiatan ini, tim pengabdian berperan sebagai pelatih sedangkan mitra berpartisipasi sebagai objek pelatihan.

3) Pendampingan pelaksanaan manajemen kelompok dan pembuatan administrasi kelompok. Pada kegiatan ini, tim pengabdian berperan sebagai pendamping yang memberikan arahan dan bimbingan pelaksanaan manajemen kelompok dan penyusunan administrasi kelompok. 


\section{Meningkatkan kemampuan mitra dalam memasarkan hasil produksinya serta memanfaatkan media promosi on line.}

Metode yang digunakan adalah melalui penyuluhan, pelatihan dan pendampingan kepada mitra. Tahapan kegiatan yang akan dilakukan adalah sebagai berikut:

a) Penyuluhan tentang arti pentingnya melakukan kegiatan pemasaran, strategi pemasaran yang efektif dan bermacam-macam media promosi (surat kabar, radio dan internet). Pada kegiatan ini, tim pengabdian berperan sebagai pemberi penyuluhan sedangkan mitra berpartisipasi sebagai objek penyuluhan.

b) Penyuluhan dan praktek pemasaran menggunakan internet. Pemasaran tidak hanya dilakukan secara konvensional namun dapat juga dilakukan melalui internet. Tahap-tahap dalam pelaksanaan pelatihan online tampak pada gambar 1 (Iro Maruto, 2013).

c) Pendampingan pelaksanaan pemasaran on-line. Pada kegiatan ini, tim pengabdian berperan sebagai pendamping yang memberikan arahan dan bimbingan pelaksanaan pemasaran on-line.

3. Penyuluhan dan pelatihan tentang desain produk batik tulis dan printing yang bervariatif sesuai dengan kebutuhan, keinginan, dan selera konsumen.

Metode yang digunakan adalah melalui penyuluhan, pelatihan dan pendampingan kepada mitra. Tahapan kegiatan yang akan dilakukan adalah sebagai berikut:

a) Penyuluhan tentang trend desain batik yang disukai pasar. Saat ini desain batik kedua kelompok cenderung monoton, tradisionil dan tidak mengikuti trend yang ada. Hal ini disebabkan karena keterbatasan kemampuan SDM dalam pengelolaan produksi yang dimiliki oleh kedua kelompok. Oleh karena itu perlu diberi pemahaman kepada kedua kelompok bahwa pengembangan desain perlu dilakukan dengan mengikuti selera pasar. Pada kegiatan ini tim pengabdian akan bertindak sebagai fasilitator sedangkan mitra akan berperan sebagai objek pelatihan.

b) Pelatihan pengembangan desain. Pelatihan desain dimulai dari mengidentifikasi semua desain produk yang dimiliki oleh mitra, yaitu meliputi semua desain yang telah dimiliki atau pernah diproduksi oleh mitra, jumlah desain yang pernah diproduksi oleh mitra, jumlah desain yang masih diproduksi sampai saat sekarang, dan jenis desain yang laris diterima pasar. kemudian menganalisis desain-desain yang diminati pasar produk batik saat ini. Produk yang dikembangkan sesuai dengan tren yang diminati pasar saat ini. Tahap selanjutnya adalah menyusun konsep desain motif batik yang akan dikembangkan, selanjutnya membuat motif desain batik, Setelah itu, membuat screen dari desain yang telah dibuat, sekaligus mempersiapkan bahan untuk memproduksi batik.

c) Pendampingan pelaksanaan pengembangan desain. Pada kegiatan ini, tim pengabdian berperan sebagai pendamping yang memberikan arahan dan bimbingan pelaksanaan pengembangan desain. Kegiatan pengabdian tidak hanya berhenti setelah kegiatan selesai, namun juga perlu dilakukan pendampingan agar dapat menjamin hasil pelatihan dapat diterapkan. Pada kegiatan ini tim pengabdian akan bertindak sebagai fasilitator sedangkan mitra akan berperan sebagai objek pelatihan. 


\section{Memberikan pelatihan batik printing dan memberikan bantuan alat-alat dan bahan pembuatan batik printing.}

Metode yang digunakan adalah melalui penyuluhan, pelatihan dan pendampingan kepada mitra. Tahapan kegiatan yang akan dilakukan adalah sebagai berikut:

a) Penyuluhan tentang batik printing, kelebihan dan kelemahannya serta proses batik printing. Pada kegiatan ini tim pengabdian akan bertindak sebagai fasilitator sedangkan mitra akan berperan sebagai objek pelatihan.

b) Pembelian peralatan dan bahan pembuatan batik printing. Setelah motif batik dibuat selanjutnya dilakukan pembelian screen dari desain yang telah dibuat. Pembuatan screen dilakukan di Kota Pekalongan. Tim pengabdian akan menfasilitasi pemesanan mesin ini dengan memperhatikan pendapat ahli

c) Pelatihan pembuatan batik printing. Kegiatan praktek pembuatan batik printing akan dilakukan dengan mengundang pelatih profesional. Setelah kegiatan selesai, kedua mesin screen tersebut akan diberikan kepada kedua kelompok. Kedua kelompok juga akan dibawa untuk melakukan studi banding ke UKM Batik Tata di Kota Sumpiuh Kabupaten Banyumas yang telah sukses memproduksi batik printing. Pada kegiatan ini tim pengabdian akan bertindak sebagai fasilitator sedangkan mitra akan berperan sebagai objek pelatihan.

\section{Rancang bangun pembuatan desain kemasan dan label untuk meningkatkan nilai jual dan nilai pelanggan (custumer value).}

Metode yang digunakan adalah melalui penyuluhan, pelatihan dan pendampingan kepada mitra. Tahapan kegiatan yang akan dilakukan adalah sebagai berikut:

a) Penyuluhan tentang arti penting desain kemasan dan label untuk meningkatkan nilai jual dan nilai pelanggan (custumer value). Pada kegiatan ini tim pengabdian akan bertindak sebagai pemberi pelatihan sedangkan mitra akan berperan sebagai objek pelatihan.

b) Praktek membuat desain produk, label dan kemasan yang menarik. Dalam kegiatan PKM IbM ini akan dikembangkan kemasan produk dan label, baik kemasan primer maupun kemasan sekunder dengan mempertimbangkan segi keindahan. Pada kegiatan ini tim pengabdian akan bertindak sebagai pelatih dan fasilitator sedangkan mitra akan berperan sebagai objek pelatihan.

c) Pendampingan pembuatan desain produk, label dan kemasan yang menarik. Pada kegiatan ini tim pengabdian akan bertindak sebagai pelatih dan fasilitator sedangkan mitra akan berperan sebagai objek pelatihan.

\section{Meningkatkan kemampuan manajemen usaha kecil dan keterampian membuat laporan keuangan.}

Metode yang digunakan adalah melalui penyuluhan, pelatihan dan pendampingan kepada mitra. Tahapan kegiatan yang akan dilakukan adalah sebagai berikut:

a) Penyuluhan tentang kemampuan manajemen usaha kecil dan keterampian membuat laporan keuangan.

Dalam melaksanakan program ini Tim Pengabdian akan memberikan pengetahuan tentang manajemen usaha kecil yang meliputi manajemen produksi, SDM, pemasaran dan keuangan. Pada kegiatan ini tim pengabdian akan bertindak sebagai pelatih dan fasilitator sedangkan mitra akan berperan sebagai objek pelatihan. 
b) Praktek penyusunan Laporan Keuangan

1) Kegiatan penyuluhan ini dilanjutkan dengan praktek penyusunan laporan keuangan. Pada kegiatan ini tim pengabdian akan bertindak sebagai pelatih dan fasilitator sedangkan mitra akan berperan sebagai objek pelatihan. Pembukuan yang diberikan meliputi pencatatan Buku kas, Buku Pembelian Tunai,Buku Pembelian Kredit, Buku Penjualan Tunai, Buku Penjualan Kredit, Buku Piutang, Buku Utang, Neraca (Balance Sheet) dan Laporan Laba Rugi.

2) Pendampingan pelaksanaan penyusunan laporan keuangan. Pada kegiatan ini, tim pengabdian berperan sebagai pendamping yang memberikan arahan dan bimbingan pelaksanaan penyusunan laporan keuangan.

\section{METODE EVALUASI}

Keberhasilan kegiatan yang akan dilakukan diukur dengan :

1) Pre test. Test ini dilakukan untuk memperoleh gambaran mengenai wawasan mitra tentang manajemen kelompok, arti penting penyusunan administrasi kelompok dan jenisjenis administrasi kelompok, manajemen pemasaran yang efektif, pemasaran on-line, desain produk batik tulis dan printing yang bervariatif sesuai dengan kebutuhan, keinginan, dan selera konsumen, batik printing dan kelebihan dan kelemahan batik printing serta dan proses batik printing, arti penting desain kemasan dan label untuk meningkatkan nilai jual dan nilai pelanggan (customer value), manajemen usaha kecil dan keterampian membuat laporan keuangan sebelum dilaksanakannya kegiatan pengabdian. Dengan tes ini dapat diketahui hal-hal apakah yang harus mendapat perhatian dalam kegiatan pengabdian kepada masyarakat ini.

2) Post test. Test ini untuk membandingkan wawasan dan pengetahuan mitra sebelum dan setelah dilaksanakannya kegiatan pengabdian dalam memahami tentang manajemen kelompok, arti penting penyusunan administrasi kelompok dan jenis-jenis administrasi kelompok, manajemen pemasaran yang efektif, pemasaran on-line, desain produk batik tulis dan printing yang bervariatif sesuai dengan kebutuhan, keinginan, dan selera konsumen, batik printing dan kelebihan dan kelemahan batik printing serta dan proses batik printing, arti penting desain kemasan dan label untuk meningkatkan nilai jual dan nilai pelanggan (customer value), manajemen usaha kecil dan keterampian membuat laporan keuangan.

3) Membandingkan tingkat pengetahuan dan kemampuan mitra dalam sebelum dan sesudah kegiatan pengabdian kepada masyarakat.

4) Membandingkan kinerja produksi dan pemasaran mitra sebelum dan sesudah kegiatan pengabdian kepada masyarakat, yang meliputi jumlah omzet penjualan, jumlah pembeli, keuntungan dan pertumbuhan penjualan sebelum dan sesudah kegiatan pengabdian kepada masyarakat.

\section{HASIL KEGIATAN}

\section{Koordinasi Kegiatan dengan ketua UKM Sekar Geang dan Capit Urang}

Koordinasi dilaksanakan pada tanggal 3 Maret 2016 dan 6 Maret 2016. Hasil koordinasi tersebut disepakati beberapa kegiatan yang akan dilakukan secara bersamasama dari kedua UKM dan beberapa kegiatan akan dilakukan secara terpisah sendiri pada lokasi UKM tersebut. 


\section{Penyuluhan Tentang Manajemen Kelompok}

Kegiatan penyuluhan manajemen kelompok dan praktek penyusunan administrasi kelompok dilaksanakan pada tanggal 10 Juni 2016. Tujuan kegiatan ini untuk meningkatkan kemampuan mitra dalam manajemen dan penyusunan administrasi kelompok. Administrasi kelompok yang diajarkan meliputi :

1) Anggaran dasar dan anggaran Rumah Tangga Kelompok

2) Komponen Anggaran Dasar

3) Komponen Anggaran Rumah Tangga (ART)

4) Administrasi kelompok

\section{Meningkatkan kemampuan mitra dalam memasarkan hasil produksinya}

Kegiatan penyuluhan manajemen pemasaran ini diberikan pengetahuan tentang caracara memasarkan produk baik dengan sistem langsung maupun sistem on line. Kegiatan yang dilaksanakan pada tanggal 15 Juli 2016 ini diikuti oleh peserta pelatihan dengan antusias.

\section{Penyuluhan Dan Pelatihan Media Promosi On Line}

Pemasaran melalui media social adalah bentuk pemasaran baik secara langsung maupun tidak langsung yang dilakukan untuk membangun kesadaran, dan tindakan untuk sesuatu merek, bisnis, orang, atau badan lain dan dilakukan dengan menggunakan alat-alat dari web sosial (Gurnelius, 2011). Kegiatan penyuluhan dan pelatihan media promosi on line dilaksanakan pada tanggal 15 Juli 2016. Media promosi on line dengan menggunakan media sosial berupa facebook, WhatsApp, dan line.

5. Penyuluhan dan pelatihan tentang desain produk batik tulis dan printing yang bervariatif sesuai dengan kebutuhan,keinginan, dan selera konsumen.

Produk adalah apapun yang dapat ditawarkan ke sebuah pasar dan bisa memuaskan sebuah keinginan atau kebutuhan (Kotler \& Amstrong, 2011). Kegiatan yang dilakukan untuk meningkatkan kualitas produk yaitu dengan penyuluhan dan pelatihan. Kegiatan penyuluhan dan pelatihan tentang desain produk batik tulis dan printing yang bervariatif dilaksanakan pada tanggal 21 Juli 2016.

6. Memberikan pelatihan batik printing dan memberikan bantuan mesin alat-alat dan bahan pembuatan batik printing.

Kegiatan penyuluhan dan pembuatan batik printing dilaksanakan sebanyak 2 kali pada tanggal 1 Agustus 2016 dan 3 Agustus 2016. Kegiatan diikuti oleh sebanyak 23 orang yang terdiri dari 10 orang dari Sekar Geang, 10 orang dari Capit Urang dan 3 orang dari perwakilan pembatik di luar kedua kelompok. Pelatihan dilakukan di UKM Batik Wardah Kec. Susukan Banjarnegara yang biasa digunakan sebagai tempat pelatihan membatik baik batik tulis, cap maupun printing. Pelatihnya adalah Bapak Budi yang merupakan pemilik UKM Batik Wardah.

Pelatihan batik tahap pertama adalah penyuluhan dan pembuatan batik printing dengan alat pembuatan batik printing. Setelah beberapa hari dengan melewati proses penjemuran, pelatihan batik tahap kedua dilakukan "nglorod" yang selanjutnya dilakukan finishing terhadap batik-batik printing hasil pelatihan tersebut. 
7. Meningkatkan Kemampuan Manajemen Usaha Kecil Dan Keterampilan Membuat Laporan Keuangan

Kegiatan penyuluhan manajemen keuangan dalam pengelolaan usaha kecil dilaksanakan pada tanggal 21 Juli 2016. Kegiatan tersebut dilanjutkan dengan praktek penyusunan administrasi keuangan.

8. Rancang Bangun Pembuatan Desain Kemasan Dan Label Untuk Meningkatkan Nilai Jual Dan Nilai Pelanggan (Customer Value)
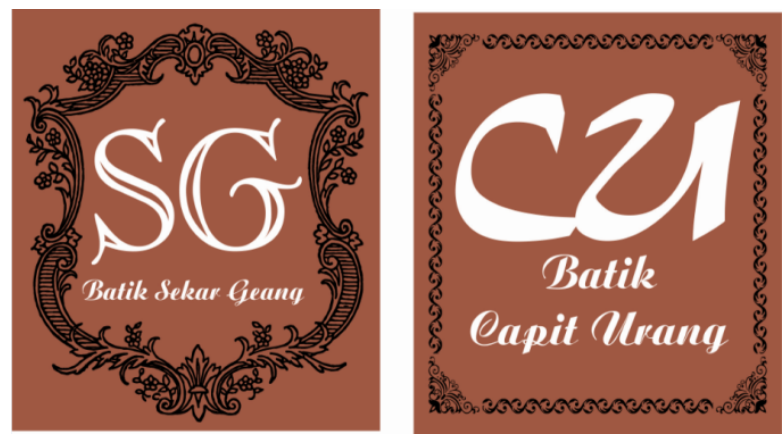

Gambar 1. Desain Logo pada Kemasan dan Label Kelompok

\section{DAFTAR PUSTAKA}

Gurnelius, S. (2011). 30-minute Sosial Media Marketing. USA: McGraw-Hill Co.

Iro, Maruto. 2013. Permasalahan di UKM Batik Dan Solusinya, www.pendidikanekonomi.com, diakses 10 Mei 2013

Kotler, Philip., Amstrong, Gary.2011. Principles of Marketing. $14^{\text {th }}$ ed. New Jersey: Pearson.

Pramudiana, Yudi, Risris R., Fitri R. 2017. Business Plan. Bandung: Remaja Rosdakarya. 